\title{
Inequalities between Women and Men Aged Over and Under Seventy Years. SABE Colombia - Survey on Health, Well-being and Aging 2015
}

\section{Desigualdades entre mujeres y hombres mayores y menores de setenta años. Encuesta Salud, Bienestar y Envejecimiento (SABE) Colombia 2015}

\author{
Cecilia de Santacruz \\ Pontificia Universidad Javeriana, Colombia \\ Diego Andrés Chavarro Carvajal ${ }^{b}$ \\ Pontificia Universidad Javeriana, Colombia \\ Luis Carlos Venegas-Sanabria \\ Hospital Universitario San Ignacio, Colombia \\ Ana Carolina Gama \\ Hospital Universitario San Ignacio, Colombia \\ Carlos Alberto Cano Gutiérrez \\ Pontificia Universidad Javeriana, Colombia
}

\footnotetext{
b Correspondence: chavarro-d@javeriana.edu.co
}

How to cite: Santacruz C de, Chavarro Carvajal DA, Venegas-Sanabria LC, Gama AC, Cano Gutiérrez $\mathrm{CA}$. Inequalities between women and men aged over and under seventy years. SABE Colombia - Survey on Health, Well-being and Aging 2015. Univ. Med. 2019;60(3). https://doi.org/10.11144/Javeriana.umed 60-3.sabe

\begin{abstract}
Introduction: The differential approach, knowing the inequalities in older adults, helps in the evaluation of their conditions and in the design of interventions, research and teaching.

Objective: To identify the peculiarities and inequalities related to the generation and sex/gender in the Colombian population of older adults. Methodology: Observational, descriptive and analytical study in which a secondary analysis of the SABE Colombia population survey was carried out.

Results and Discussion: We present the results according to the inequality between men and women and by generation; of monetary poverty and mobility, violence and displacement. Economic income. Situation during childhood. Access to public services. Family environment. Health conditions.

Conclusion: The disparities are related to representations and practices related to gender and age, less evident in the economic aspect. Actions must be reinforced to improve the living conditions of all and the social conceptions and imaginaries that naturalize the differences, and to avoid new disadvantages due to the healthy achievements of aging.

Keywords

inequalities; gender; elder; aging.
\end{abstract}

\section{RESUMEN}

Introducción: El abordaje diferencial, sabidas las desigualdades e inequidades en los adultos mayores, ayuda en la evaluación de sus 
condiciones y en el diseño de intervenciones, la investigación y la docencia.

Objetivo: Identificar las peculiaridades y las desigualdades relativas a la generación y sexo/género en la población colombiana de personas adultas mayores.

Metodología: Estudio observacional, descriptivo y analítico que realizó un análisis secundario de la encuesta poblacional del estudio SABE Colombia.

Resultados y discusión: Se exponen los resultados según desigualdad entre hombres y mujeres y por generación; de pobreza monetaria y movilidad, violencia y desplazamiento. Ingresos económicos. Situación durante la infancia. Acceso a servicios públicos. Entorno familiar. Condiciones de salud.

Conclusión: Las disparidades están relacionadas con representaciones y prácticas vinculadas al género y a la edad, menos evidentes en lo económico. Deben reforzarse acciones para mejorar las condiciones de vida de todos y las concepciones e imaginarios que naturalizan las diferencias, y para evitar nuevas desventajas por los logros saludables del envejecimiento.

Palabras clave

desigualdades; género; adulto mayor; envejecimiento.

\section{Introduction}

The term generation not only refers to age, but also the context in which its members were born and grew up, and the historical and public dimensions combine with individual and family dimensions in a "social generation," which is the result of the fusion and reciprocal transformation of biographical time and historical time (1). The notion of gender, on the other hand, belongs to the symbolic order, just as age is a cultural construct, in this case about sexual differences. The sex-gender system is also referred to. In the field of old age and aging, the material and social representation disparities between men and women become evident.

The coincidence of each of the two generations (over and under 70 years of age) with the historical, social and development changes experienced by the country make a difference in relation to urbanization, the adoption of public health policies, and the impact on the epidemiological profile with a significant decrease in infectious causes (2), in child mortality rates, in the fertility rate, and a greater participation of women in the labor force
(3), literacy (4), improvements in the quality of life, opportunities and legal modernization (5).

There are different assessments of inequalities in terms of gender - inequality, disparity, inequity, empowerment, gender development, women's economic opportunities, health, legal and social status, participation and political empowerment-(6) and health in the different age groups that evaluate health conditions and access to services. For the elderly, inequalities are examined in terms of access to health services and health outcomes: morbidity, disability and mortality (7). The Ministry of Health and Social Protection points out that the equity analysis in health compares groups in relation to mortality, morbidity, disability and care outcomes, although it always recommends to make a descriptive analysis of the differences using more than one indicator and interpreting the results by contextualizing them according to the variables and the reasons and circumstances for their determination $(8,9)$.

In recent years there has been an increase in research on older people in the country, and the Survey on Health, Well-being and Aging (SABE) Colombia 2015 (10) offers comprehensive and complete information on people who are over 60 years old (more than five million at the time of the study). This secondary analysis of the results aims to identify the peculiarities and inequalities related to generation and sex/gender in that population, recognizing their expressions in the process of aging and in old age in a sociohistorical context, not only to show the disparities, but to reinforce the means to correct them.

\section{Methodology}

This was an observational, descriptive and analytical study in which a secondary analysis of the population of the SABE Colombia survey was carried out.

SABE Colombia is a descriptive population study on health, aging and wellbeing of the Colombian population over the age of sixty, which assessed determinants of active aging (socioeconomic, social environment, physical 
environment, personal factors, behavioral factors, health conditions and use and access to health services) and three anthropometric measurements (blood pressure, physical function and hematological and biochemical parameters), based on three components: qualitative study, survey of family caregivers, and population survey (probabilistic sampling, by conglomerates, multistage in urban and rural areas, surveying 23,694 people in their homes).

In the secondary analysis, the following indicators and dimensions of the SABE survey were considered:

Dependent variables: differences between women and men, between those aged over and under 70 years, and monetary poverty.

Independent variables: Included in the "gender equality and generation" construct, prepared with a view to selecting and organizing variables within the SABE database, for a descriptive approach to inequalities. It was based on the three-gap approach (11): educational, economic and empowerment (or strengthening), adjusting the indicators according to the available data and the conceptual and methodological orientations, as follows:

Education gap: literacy level (knowing how to read and write, regardless of the level of education), and the highest level of education attained (primary education, secondary or tertiary education).

Economic gap: main work activity (work to which he/she dedicated more time, considers him/herself to be currently working, currently working); age at which he/she started working (having had a paid job, age at which hel she started working); reasons for not having worked (reason why he/she never worked) and degree of monetary poverty (being below the 2015 National Administrative Department of Statistics' monetary poverty threshold (12) (total monthly income regardless of its origin and the number of people economically dependent on the respondent).

Strengthening gap: several modifications were made to the Social Watch proposal (11), due to the characteristics of the surveyed population. Then, starting from the framework, the strengthening variables were associated with the assumption of power in daily life (economic dependence, relationship with the head of the household, other people depend on the respondent, having people who depend economically and being the head of the household, type of affiliation to the health system, participation in any social group [religious, sports, political, cultural, community, ecological, trade, ethnic, health, older people, gymnastics, exercise or physical activity], abuse: by a family member or a stranger, access to technology, main means of transportation, sex life: importance of sexual life [unimportant, important or very important] and knowledge of sexual rights [violence-free sexual life with legal protection against sexual violence; to have a same-sex relationship; to a pleasant sexual life]).

The analysis between sexes and generation was carried out dividing the results by men and women. Each of these groups was subsequently organized according to generation (over and under 70 years of age), and the results were also separated by the presence or absence of monetary poverty. Consideration was given to aspects related to mobility, displacement, source of the economic income, access to public services, family environment, health situations and childhood situations.

Statistical analysis (SPSS version 24 statistical software): the categorical variables were classified as percentages, and the differences were analyzed with chi-square. Quantitative variables were represented as mean and standard deviation (variables with normal distribution), and as median and interquartile range (variables without normal distribution). The differences between the groups for the continuous variables with normal distribution were analyzed with the Student's T test, and with the non-parametric Mann-Whitney $U$ test, if the variable did not meet this criterion. The significance was defined as a value of less than 0.05 .

Strengths and limitations: its strengths refer to the use of the results of health conditions and quality of life of the first study of the population of adults over the age of 60 , as well as to follow the international guidelines previously used in 
other capital cities in Latin America, adapted to the Colombian social and historical situation. Its limitations are due to the fact that SABE Colombia is a cross-sectional study that does not allow establishing causality, and the possible memory biases of self-reported data, as is the case with population-based studies.

Ethical considerations: the study was approved by the Ethics and Research Committee of the Pontificia Universidad Javeriana and Hospital Universitario San Ignacio. For its part, SABE Colombia was financed by the Ministry of Health, through Colciencias (Colombia's Administrative Department of Science, Technology and Innovation). It was approved by the Ethics Committees of the universities of Caldas and Valle. All the participants signed an informed consent, in order to comply with the ethical principles of the World Medical Association (Declaration of Helsinki) and the current national regulations.

\section{Results}

The results of the analysis of the data of 23,694 subjects, 13,582 (57.32\%) women, emphasize the differences between sexes, differences by generation and by sex and generation, according to monetary poverty.

Sex differences (Table 1). Statistically significant differences were found in the education gap in the group of people whose highest educational level was primary education, in favor of women $(55.8 \%$ vs. $57.6 \%, \mathrm{p}=0.007)$, while in tertiary education there was a significant difference in favor of men $(7.2 \%$ vs. $5.4 \%, \mathrm{p}=$ $0.000)$. In the economic gap, the majority of men (99.1\%) had worked and received payment at least once in their life, compared to $78.4 \%$ of women. Among the group of women who never worked, family care $(58.3 \%)$ and home care $(14.8 \%)$ were the most frequent reasons; in the case of men, lack of opportunities $(32.3 \%)$ and health problems (29\%) were the most frequent reasons. The most common work in men and women $(35.5 \%$ and $33.8 \%$, respectively) was that of worker or employee; but in the case of women domestic work predominated $(28.9 \%$ vs. $0.3 \%$, p $=0.000)$, and farm work and day laborer in the case of men $(37.9 \%$ vs. $9.8 \%, \mathrm{p}=0.000)$.

\section{Table 1}

Equality construct: differences between women and men

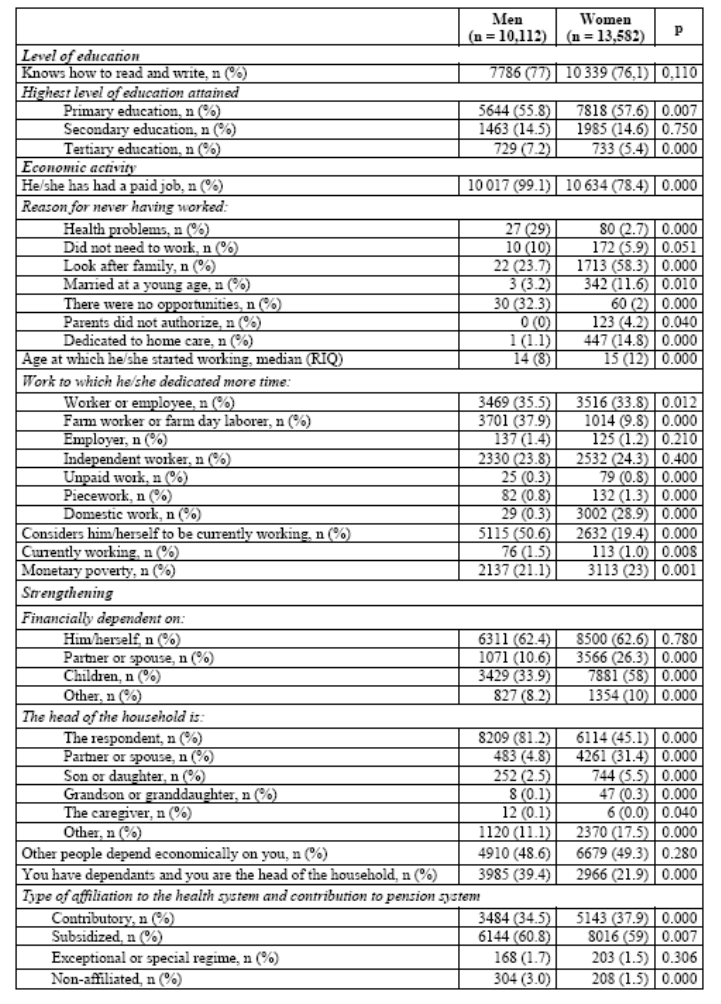


Table 1 (cont.)

Equality construct: differences between women and men

\begin{tabular}{|c|c|c|c|}
\hline Contributes to the pension system, $\mathrm{n}(\%)$ & $816(8.1)$ & $773(5.7)$ & 0.00 \\
\hline Social participation, $\mathrm{n}(\%)$ & $4042(40)$ & $6386(47)$ & 0.000 \\
\hline \multicolumn{4}{|l|}{ Abuse: } \\
\hline Has suffered abuse from a family member, $n(\%)$ & $1241(14.9)$ & $1929(18.1)$ & 0.00 \\
\hline Has suffered abuse from a stranger, $\mathrm{n}(\%)$ & $563(6.7)$ & $650(6.1)$ & \\
\hline If he/ she suffered abuse from a stranger, did he she seek help?, $\mathrm{n}(\%)$ & $343(30.5)$ & $396(32.6)$ & 0.268 \\
\hline \multicolumn{4}{|l|}{ Reason why he she did not seek help: } \\
\hline Did not know where to $g \circ, \mathrm{n}(\%)$ & $118(10.5)$ & $118(9.7)$ & 0.538 \\
\hline Felt ashamed or humiliated, $n(\%)$ & $17(1.5)$ & $31(2.6)$ & 0.076 \\
\hline It is part of life (normal), $n(\%)$ & $230(20.4)$ & $196(16.1)$ & 0.007 \\
\hline Feels that he/she deserves to be abused, $n(\%)$ & $2(0.2)$ & $1(0.1)$ & 0.520 \\
\hline Fear of being abandoned, $\mathrm{n}(\%)$ & $11(1.0)$ & $9(0.7)$ & 0.535 \\
\hline Fear of continuing to be abused, $\mathrm{n}(\%)$ & $49(4.4)$ & $61(5.0)$ & 0.445 \\
\hline $\mathrm{He} /$ she does not believe in justice, $\mathrm{n}(\%)$ & $240(21.3)$ & $230(18.9)$ & 0.150 \\
\hline \multicolumn{4}{|l|}{ Access to communication technologies } \\
\hline Knows how to use a computer, $\mathrm{n}(\%)$ & $1062(10.5)$ & $976(7.2)$ & 0.000 \\
\hline Knows how to use a cell phone, $\mathrm{n}(\%)$ & $6832(67.6)$ & $8716(64.2)$ & 0.000 \\
\hline Has a personal computer, $\mathrm{n}(\%)$ & $494(4.9)$ & $464(3.4)$ & 0.000 \\
\hline Has a personal cell phone, $\mathrm{n}(\%)$ & $6194(61.3)$ & $8318(61.2)$ & 0.986 \\
\hline \multicolumn{4}{|l|}{ Main means of transportation: } \\
\hline Public transportation, $n(\%)$ & $4833(47.8)$ & $8444(62.2)$ & 0.000 \\
\hline Private car, $\mathbf{n}(\%)$ & $762(7.5)$ & $988(7.3)$ & 0.447 \\
\hline Motorcycle, $\mathrm{n}(\%)$ & $1656(16.4)$ & $1834(13.5)$ & 0.000 \\
\hline Bicycle, $\mathrm{n}(\%)$ & $777(7.7)$ & $51(0.4)$ & 0.000 \\
\hline Walks, $\mathrm{n}(\%)$ & $1560(15.4)$ & $1868(13.8)$ & 0.000 \\
\hline Other, $\mathrm{n}(\%)$ & $455(4.5)$ & $229(1.7)$ & 0.000 \\
\hline \multicolumn{4}{|l|}{ Inportance of sexual life: } \\
\hline importance, $\mathrm{n}(\%)$ & $2536(30.7)$ & $7718(73.8)$ & 0.000 \\
\hline \multirow{2}{*}{\multicolumn{4}{|c|}{ Knows or has heard about the following sexual rights: }} \\
\hline & & & \\
\hline $\begin{array}{l}\text { Violence-fiee sexual life with legal protection against sexual } \\
\text { violence, } \mathrm{n}(\%)\end{array}$ & $5362(64.9)$ & $6745(64.3)$ & 0.353 \\
\hline Right to have a same-sex relationship, n(\%) & 66.9) & $7371(70.3)$ & \\
\hline Right to a pleasant sexual & .7) & $6319(60$ & \\
\hline
\end{tabular}

Monetary poverty showed a significant difference: it was higher in women $(21.1 \%$ vs. $23.0 \%, p=0.001$ ), as in the strengthening gap, with greater economic dependence, higher rate of abuse by relatives, less familiar with the use of technologies, less access to a personal computer $(\mathrm{p}=0.000)$, less importance of sexuality in the lives of the respondents, less knowledge of the right to have a pleasant sexual life and to have a same-sex relationship.

Differences between generations (Tables 2 and 3). In both sexes, differences were found between people over and under the age of 70 . In the education gap there are significant differences in literacy, in secondary and tertiary education in favor of people under the age of 70 in both sexes.
Table 2

Equality construct: differences between women over and under the age of 70

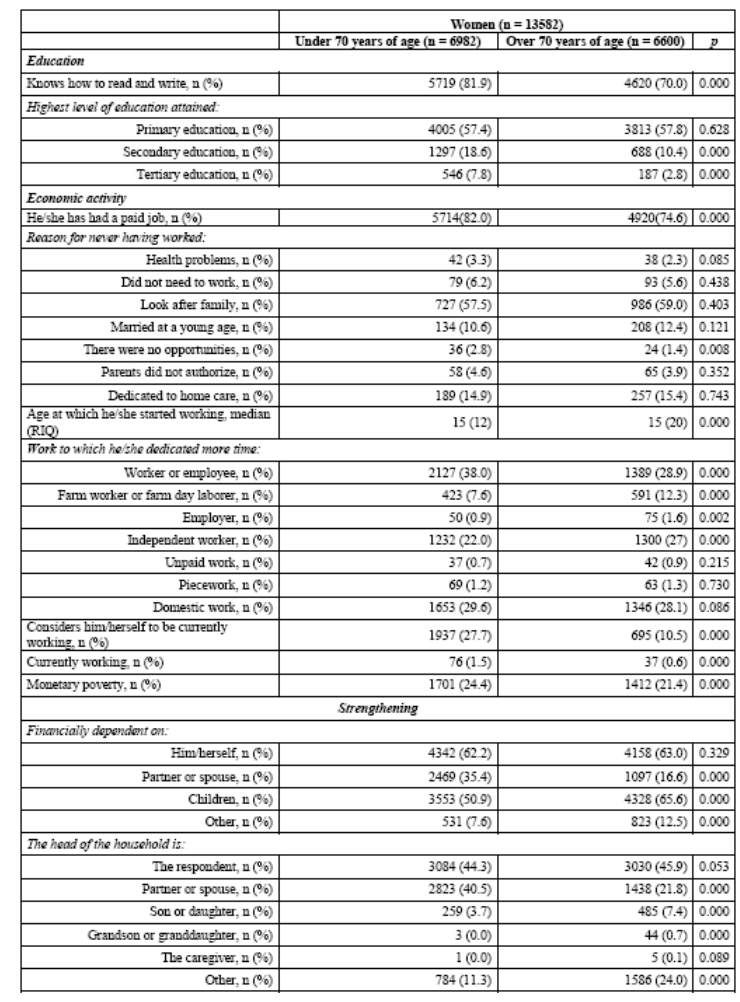


Table 2 (cont.)

Equality construct: differences between women over and under the age of 70

\begin{tabular}{|c|c|c|c|}
\hline $\begin{array}{l}\text { Other people depend economically on you, in } \\
\text { (\%) }\end{array}$ & $3491(50.1)$ & $3188(48.4)$ & 0.047 \\
\hline $\begin{array}{l}\begin{array}{l}\text { You have dependants and you are the head of } \\
\text { the household, n }(\%)\end{array} \\
\end{array}$ & $1553(22.3)$ & $1413(21.4)$ & 0.218 \\
\hline \multicolumn{4}{|c|}{ Type of affiliation to the hoalth system and contribution to pension systom } \\
\hline Coutributory, $\mathrm{n} \%$ \%) & $2706(38.8)$ & $2437(36.9)$ & 0.028 \\
\hline Subsidized, n (\%) & 4036 (57.8) & $3980(60.3)$ & 0.003 \\
\hline Exceptional or special regime, $\mathrm{n}(\%)$ & 113 (1.6) & $90(1.4)$ & 0.221 \\
\hline Nou-affiliated, $\mathrm{n}(\%)$ & $123(1.8)$ & $85(1.3)$ & 0.025 \\
\hline Contributes to the peasion system, $\mathrm{n}(\%)$ & $488(7.0)$ & $285(4.3)$ & 0.000 \\
\hline Social participation, a (\%) & $3487(49.9)$ & $2899(43.9)$ & 0.000 \\
\hline \multicolumn{4}{|l|}{ Abiuse: } \\
\hline $\begin{array}{l}\text { Has suffered abuse from a family member, } \mathrm{n} \\
\text { (\%) }\end{array}$ & 1237 (19.6) & $692(16.0)$ & 0.000 \\
\hline Has suffered abuse from a stranger, $\mathrm{n}(\%)$ & $455(7.2)$ & $195(4.5)$ & 0.000 \\
\hline $\begin{array}{l}\text { If be she suffered abuse from a stranger, did } \\
\text { be she seek help?, n (\%) }\end{array}$ & $285(34.7)$ & $111(28.2)$ & 0.025 \\
\hline \multicolumn{4}{|l|}{ Reassou why he she did not seek belp: } \\
\hline Did not know where to go, $n(\%)$ & $165(2.4)$ & $63(1.0)$ & 0.000 \\
\hline Felt asbamed or humiliated, $\mathrm{n}(\%)$ & $8(0.1)$ & $3(0.0)$ & 0.157 \\
\hline It is part of life (normal), $\mathrm{n}(\%)$ & $4(0.1)$ & $3(0.0)$ & 0.761 \\
\hline Feels that he she deserves to be abussed, $\mathrm{n}(\%)$ & $65(0.9)$ & $32(0.5)$ & 0.002 \\
\hline Fear of being abandoned, $\mathrm{n}(\%)$ & $48(0.7)$ & $18(0.3)$ & 0.001 \\
\hline Fear of continuing to be abused, $\mathrm{n}(\%)$ & $4(0.1)$ & $2(0.0)$ & 0.454 \\
\hline He'she does not believe in justice, $\mathrm{n}(\%)$ & $6(0.1)$ & $0(0.0)$ & 0.017 \\
\hline \multicolumn{4}{|l|}{\begin{tabular}{|l|l|} 
Acceess to communicication technologies \\
\end{tabular}} \\
\hline Knows how to use a conputer, $\mathrm{n}(\%)$ & $765(11.0)$ & $211(3.2)$ & 0.000 \\
\hline Knows bow to use a cell phone, $n$ (\%) & 5358 (76.7) & $3358(50.9)$ & 0.000 \\
\hline $\begin{array}{l}\text { Has a persoval computer, } \mathrm{B}(\%) \\
\end{array}$ & $340(4.9)$ & $124(1.9)$ & 0.000 \\
\hline Has a personal cell phone, $\mathrm{n}(\%)$ & 5069 (72.6) & $3249(49.2)$ & 0.000 \\
\hline \multicolumn{4}{|l|}{\begin{tabular}{|l|} 
Main means of transponation: \\
\end{tabular}} \\
\hline Public trabsportatiou, $\mathrm{n}(\%)$ & $4252(60.9)$ & $4192(63.5)$ & 0.002 \\
\hline Pivate car, $\mathrm{n}(\%)$ & $436(6.2)$ & $552(8.4)$ & 0.000 \\
\hline Motorcycle, $\mathrm{n}(\%)$ & 1099 (15.7) & 735 (11.1) & 0.000 \\
\hline Bicycle, $\mathrm{n}(\%)$ & $37(0.5)$ & $14(0.2)$ & 0.002 \\
\hline Walks, $\mathrm{n}(\%)$ & $989(14.2)$ & 879 (13.3) & 0.152 \\
\hline Other, $\mathrm{n}(\%)$ & $125(1.8)$ & $104(1.6)$ & 0.332 \\
\hline \multicolumn{4}{|l|}{\begin{tabular}{|l} 
Inportance of sexial life: \\
\end{tabular}} \\
\hline Little or no importance, $\mathrm{n}(\%)$ & $4362(69.9)$ & $3356(79.7)$ & 0.000 \\
\hline Important of very important, $\mathrm{n}$ (\%) & $1877(30.1)$ & $857(20.3)$ & 0.000 \\
\hline \multicolumn{4}{|l|}{$\begin{array}{l}\begin{array}{l}\text { Knows or bas heard about the following } \\
\text { sesual nights: }\end{array} \\
\end{array}$} \\
\hline \begin{tabular}{|c|} 
Violence-free sexual life with legal \\
protection
\end{tabular} & $4344(69.5)$ & $2401(56.6)$ & 0.000 \\
\hline \begin{tabular}{|l|} 
Riglatr to have a same-sex relationship, i $(\%)$ \\
\end{tabular} & $4659(74.5)$ & $2712(64.0)$ & 0.000 \\
\hline Rigat to a pleasant sexual life, $\mathrm{n}(\%)$ & $4175(67.4)$ & $2144(51.1)$ & 0.000 \\
\hline
\end{tabular}

Table 3

Equality construct: differences between men over and under the age of 70

\begin{tabular}{|c|c|c|c|}
\hline & \multicolumn{3}{|c|}{$\operatorname{Men}(n=10112)$} \\
\hline & $\begin{array}{l}\text { Under } 7 \text { years of age } \\
\text { (n=sl19) }\end{array}$ & \begin{tabular}{|l|l|} 
Orer 70 years of age \\
$(\mathrm{m}=993)$
\end{tabular} & $p$ \\
\hline \multicolumn{4}{|c|}{ Education } \\
\hline Kavws how to read avd write, $\mathrm{n}(\%)$ & $4201(82.1)$ & 3585 (71.8) & 0.000 \\
\hline \multicolumn{4}{|l|}{ Highest level of ehication attained: } \\
\hline Primary efucation, a $(\%)$ & $2825(55.2)$ & $2819(56.5)$ & 0.198 \\
\hline Secoodsry eturation a (\%) & $928(18.1)$ & $535(10.7)$ & 0.000 \\
\hline Tertiary edusation, a $(\%)$ & $510(10.0)$ & $219(4.4)$ & 0.000 \\
\hline \multicolumn{4}{|c|}{ Economic activity } \\
\hline Hes ste has had a ped job, $1(\%)$ & 5074 (99.2) & $4943(99.1)$ & 0.059 \\
\hline \multicolumn{4}{|l|}{ Resson for nower havigg werkian: } \\
\hline Health problems, $\mathrm{a} \%)$ & $14(28.0)$ & $13(302)$ & 0.813 \\
\hline Did Dot peed to work, $\mathrm{a}(\%)$ & $6(120)$ & $4(9,3)$ & 0.675 \\
\hline Look after fmily, a (\%) & $11(220)$ & 11 (25.6) & 0.685 \\
\hline Narried at a youmg age, $\mathrm{a}(\%)$ & $2(4.0)$ & $1(23)$ & 0.649 \\
\hline There were so opportwinite, $\mathrm{n}(\%)$ & $16(32.0)$ & $14(320)$ & 0.954 \\
\hline Poveeds did ovo athorize, a $(\%)$ & $0(0,0)$ & $0(0.0)$ & \\
\hline Deếcated to horre crese, $\mathrm{a}(\%)$ & $1(20)$ & $0(0.0)$ & 0351 \\
\hline 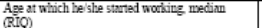 & $14(8)$ & $13(8)$ & 0.019 \\
\hline \multicolumn{4}{|l|}{ 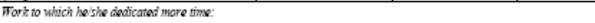 } \\
\hline Worker or employee, a $(\%)$ & 1908 (38.4) & $1561(32.5)$ & 0.000 \\
\hline Fanm worker or fimn day hatoreer, $\mathrm{a}(\%)$ & $1678(33.8)$ & $2023(42.1)$ & 0.000 \\
\hline Enploye, a (\%) & $55(1.2)$ & $79(1.6)$ & 0.046 \\
\hline Independest woiker, a (\%) & $1249(25.2)$ & $1081(225)$ & 0.002 \\
\hline Usppid work, a $(\%)$ & $17(0.3)$ & $8(02)$ & 0.085 \\
\hline Piecework, a (\%) & $38(0.8)$ & $44(0.9)$ & 0.419 \\
\hline Domestic work, a (\%) & $15(0.3)$ & $14(0.3)$ & 0.919 \\
\hline 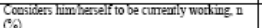 & $3407(66.6)$ & $1708(345)$ & 0.000 \\
\hline Cureatly working $\mathrm{n}(\%)$ & $41(2.4)$ & $35(1.1)$ & 0.000 \\
\hline Mocenasy poretry, i (\%) & 1008 (19.7) & $1129(22.0)$ & 0.000 \\
\hline \multicolumn{4}{|c|}{ Strengthening } \\
\hline \multicolumn{4}{|l|}{ Frnacially dependient on: } \\
\hline Fim herself, $\mathrm{n}(\%)$ & $3150(61.5)$ & $3161(63.3)$ & 0.066 \\
\hline Partar or spouse, $\mathrm{a}(\%)$ & 595 (11.0) & $476(9.5)$ & 0.001 \\
\hline Clividren n $(\%)$ & $1192(23.3)$ & $2237(4.8)$ & 0.000 \\
\hline Other, a $(\%)$ & $333(6.5)$ & \begin{tabular}{|l|l|}
$494(99)$ \\
\end{tabular} & 0.000 \\
\hline \multicolumn{4}{|l|}{ The hand of the houseliold is: } \\
\hline The respooder, $\mathrm{a}(\%)$ & $4383(85.7)$ & $3826(76.7)$ & 0.000 \\
\hline Purter or spouse, $\mathrm{n}(\%)$ & $217(42)$ & $266(5.3)$ & 0.011 \\
\hline Son of dingliter, a $(\%)$ & $102(20)$ & $150(3.0)$ & 0.001 \\
\hline
\end{tabular}


Table 3 (cont.)

Equality construct: differences between men over and under the age of 70

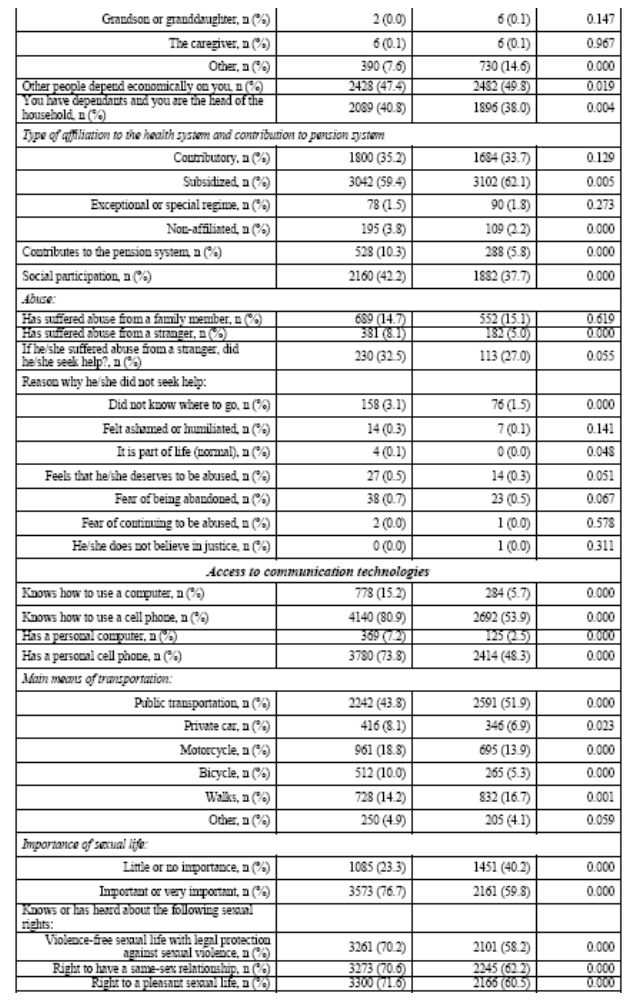

Statistically significant differences were found for women over 70 years of age, with less access to paid work, greater economic dependence, less affiliation to the health system in a contributory regime, lower percentage of contribution to the pension system, social participation, access to communication technologies and the importance of sexual life, and more abuse by family members.

In men over 70 years of age, statistically significant differences are observed at an earlier age at the beginning of working life, greater dedication to jobs such as a worker, day laborer and independent work, greater monetary poverty, greater economic dependence, less affiliation to the health system to the contributory regime, lower percentage of contribution to the pension system, less social participation, less access to communication technologies, less knowledge of sexual rights and more abuse by a stranger.

Differences between women and men of the two generations according to monetary poverty (Table 4):
Mobility, violence and displacement. Women under the age of 70 without monetary poverty have always lived in rural areas, unlike older women in the same economic conditions, who have moved ( $14 \%$ vs. $12.2 \%, \mathrm{p}=0.007)$. In men without monetary poverty there is also a significant difference: those over the age of 70 have remained in rural areas more than younger ones $(13.5 \%$ vs. $15.8 \%, p=0.004)$. Regarding displacement due to the armed conflict, there are no differences in the group of women neither by generation nor by economic income; on the other hand, men over 70 years of age both with monetary poverty $(17.5 \%$ vs. $26.4 \%, \mathrm{p}=0.00)$ and without it $(12.5 \%$ vs. $20 \%, \mathrm{p}=0.00)$ suffered more displacement than the younger ones.

Economic income. Although there are no statistically significant differences, more than $80 \%$ of people (men and women in both generations) have a low economic level, more men under the age of 70 receive a pension compared to those over 70, without being affected by monetary poverty $(26.3 \%$ vs. $22.2 \%$, $\mathrm{p}=0.025$ and $22.9 \%$ vs. $17.7 \%, \mathrm{p}=0.00)$. On the other hand, more women without monetary poverty over the age of 70 receive a pension compared to younger women $(14.9 \%$ vs. $20.6 \%$, $\mathrm{p}=0.00$ ); no significant difference was observed in the group of women with monetary poverty. Regarding the receipt of subsidies, we found that in the group of women without a link to the existence or non-existence of monetary poverty, more women under the age of 70 receive subsidies compared to those over $70(40.7 \%$ vs. $28.9 \%$, p $=0.00$ and $34.7 \%$ vs. $24.8 \%, p=0.00$ ), this is different from what is observed in men: those over 70 receive more subsidies than younger ones, without any link with the existence or nonexistence of monetary poverty ( $27 \%$ vs. $33,9 \%$, p $=0.001$ and $24.4 \%$ vs. $31.1 \%, \mathrm{p}=0.00$ ).

Situation during childhood. Between 26.1\% and $31.8 \%$ of respondents experienced hunger during childhood. With a significant difference in the group of men, those under 70 years of age experienced more hunger than those over 70 years, in both subgroups with and without monetary poverty $(44.2 \%$ vs. $38.6 \% \mathrm{p}=0.02$ and $27.4 \%$ vs. $24.6 \%, \mathrm{p}=0.01)$. 
Access to public services. In all cases, access to electricity is greater than $95.7 \%$; to water supply, greater than $80 \%$; to sewerage, greater than $62.2 \%$; access to natural gas is the lowest, between $48.7 \%$ and $79.4 \%$. Both men and women under 70 have greater access to public services with significant differences compared to those over 70, with or without monetary poverty.

Family environment. The majority of men and women, with and without monetary poverty, live with their children; in all cases, more than $91.2 \%$ of respondents have had children. More women over 70 live alone, without monetary poverty affecting this item $(6.8 \%$ vs. $8.7 \%, p=0.009$ [with poverty] and $6.7 \%$ vs. $9.8 \%, p=0.00$ [without poverty]).

Health conditions. In all cases (men and women with and without monetary poverty), those under 70 have better functionality, measured by a Barthel score higher than 90 . On the other hand, those over 70 have a lower cognitive status, assessed with a Minimental score lower than 24, and suffer more cardiovascular disease, respiratory disease, diabetes mellitus and osteoarticular pathology compared to the younger ones, without being affected by the existence or non-existence of monetary poverty. All these aspects have statistically significant differences.

\section{Table 4}

Gender and generation differences according to monetary poverty

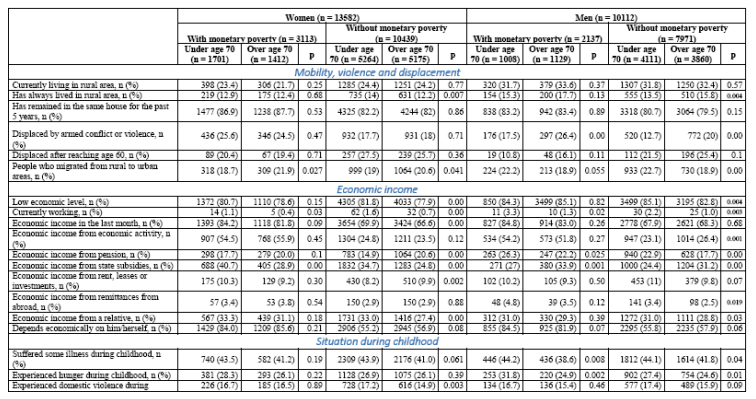

Table 4 (cont.)

Gender and generation differences according to

monetary poverty

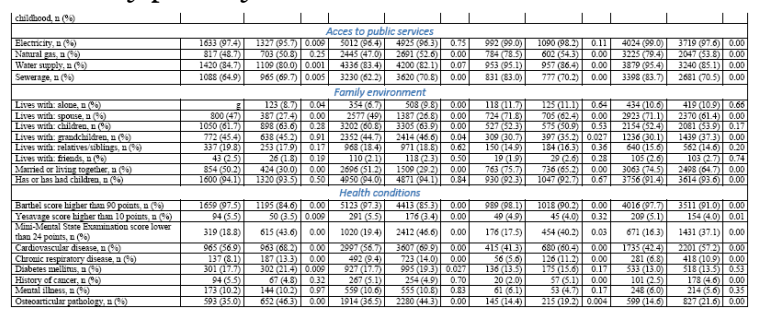

\section{Discussion}

Sex/gender equality and generation. Regarding the educational aspects, there are gaps between men and women and generation. First, the highest percentages of illiteracy (women: 30\%, men: $28.2 \%$ ) are among those over 70 ; percentages decrease significantly for the second generation analyzed (women: $18.1 \%$, men: $17.9 \%$ ). In terms of formal education, more than half of the elderly people only attended primary education (slightly higher figure for men); secondary education was more frequent for the second generation (women: 18.1\%, men: 18.6\%) than for the first generation (women: $10.7 \%$, men: $10.4 \%$ ). This situation is similar for tertiary education, but more men reached this level (under 70 years old: women: $7.8 \%$; men: $10.0 \%$; over 70 years old: women: $2.8 \%$; men: 4.4\%). These disparities allow to infer the impact of the transformations in the country's education system.

Now, beyond these inequalities, we should point out those inequalities that older people present compared to the rest of the population, derived from the restrictions on access to educational opportunities during their childhood and youth. Although in the thirties primary education became free and mandatory, and its budget increased, as well as the number of students (with variations by departments), this was insufficient, and with little student retention. Cajiao (13) explains that during the first half of the century, Colombia was an agrarian society, so education was a family and community task aimed at resolving aspects of daily life and transmitting values and the expected behavior. 
After the fifties, education became primarily the responsibility of the State, with a greater supply, pressured by migration from the countryside and the demands of industrialization.

With regard to the economic gap, some differences appear between the generations; but the truly striking correspond to sex. One of these differences is that almost all men were once paid for their work (99.2\% and 99.1\%); women received between $17.2 \%$ and $24.5 \%$ less payment, compared to men of their generation (82.0\% and $74.6 \%$ ). Likewise, the reasons given for not having worked make the gender issue clear. $87.6 \%$ of women reported that this was due to having to take care of the family, to dedicate themselves to housework, to having gotten married at a young age or not having parental permission; in men, these reasons only reach $28 \%$. On the other hand, more than $60 \%$ of men stated that this was due to health problems and lack of opportunities; in the case of women, only $6.1 \%$ of those under 70 and $3.7 \%$ of those over 70 years stated this reason. The type of work performed confirms the above: domestic work for women $(29.6 \%$ for those under 70 and $28.1 \%$ for those over 70$)$ vs. men $(0.3 \%)$; day laborer or farm worker (women: $7.6 \%$ and $12.3 \%$ ) and men (33.8\% and $42.1 \%)$.

Monetary poverty in their current situation (men: $21.1 \%$ vs. women: $23.0 \%$ ) speaks of the possibility of entering the labor market for family members; in this case, it depends on women's unpaid work. The greater poverty that women suffer compared to men is due both to the dedication to life-supporting work and to lower-paid, partial occupations, entering and leaving the labor market, and the fact that their economic contributions are considered to be complementary, because they help "to avoid family's poverty, but not their individual poverty" (14).

On the other hand, the age of initiation of working life (towards the age of 14) is similar; a little lower in the case of older men. This coincides with the fact that until after the middle of the last century it was accepted that children and young people worked. Approximately one third of the elderly people worked as a worker or employee, being more frequent in the second generation (under 70 years old: $38.0 \%$ for women and $38.4 \%$ for men; over 70 years old: $28.9 \%$ for women and $32.5 \%$ for men). In should also be emphasized that only between $0.9 \%$ and $1.6 \%$ of older people spent most of their time to be an employer; the common condition in the older population was that of subordination. $85 \%$ of the jobs were informal, and $76 \%$ were independent. In general, the human capital of older people is lower, compared to the rest of the working population; women, the inhabitants of rural areas and older people have the worst social and labor conditions (15).

The fact that a large number of older people continue to work has been explained by reasons such as an uncritical acceptance of the fear of dependence, catastrophic demographic information, the demands of active aging and the power of science and technology to guarantee these achievements. This can further diminish the social security benefits for the elderly (16). However, there is a difference between men and women who are willing to work and those who can find work (men: $50.6 \%$ and $1.5 \% ; 19.4 \%$ and $1.0 \%)$.

In the strengthening gap, similar percentages of women and men of both generations (a little over $60 \%$ ) depend on themselves; for the rest there are discrepancies, because more women than men depend on the spouse or partner, particularly the youngest (35.4\%), and less older men $(9.5 \%)$. On the other hand, many more women than men depend on their children; but this condition is more frequent in all people older than 70 years. Although the support provided by these family networks is valuable, such subordination to children and relatives can affect the autonomy of women and the regularity of income (17). The role of head of the household is mainly in the hands of men $(85.7 \%$ and $76.7 \%)$, especially those under 70 , which gives continuity to the conception of authority and control associated with men.

The majority of older people are affiliated to the subsidized health system (around 60\%); this is another of the signs of dependency of this population and, as expected, very few of these 
people contribute to the pension system, and this is particularly true in the case of women. It is possible that the situation of undervaluation of old people and their submission to other people is a reason for abuse by family members, which is observed in up to one fifth of women.

On the other hand, there is low participation (which confirms the findings of the 2015 National Mental Health Survey), with some points in favor of women in this case. The second generation (those who are younger) has much more access to communication technologies; on average, almost $80 \%$ of men and women know how to use mobile phones, and a slightly smaller figure own their own telephone. In contrast, a smaller number have access to a computer, especially women. Such data should be analyzed in light of what some have called new illiteracy.

In accordance with the proposed framework, there are divergent figures regarding the assessment of the importance of sexuality and the knowledge of rights in this regard, and there is a predominance of interest and knowledge on the part of men and those who are younger, which allows to glimpse the gender shaping.

Sex/gender, generation and monetary poverty. The analysis of the results of the monetary poverty dimension by sex/gender and generation shows five central points that warn about the importance of effectively developing the Colombian policy of human aging and old age 2014-2024.

In the first place, according to the National Administrative Department of Statistics, in 2015 (year in which the SABE survey was conducted) $27.8 \%$ of the Colombian population lived in a situation of monetary poverty, that is, people who did not have enough income to acquire the basic basket of food and other services. In other words, their income is below the poverty line, and in rural areas the percentage of people in this situation can reach $36 \%$ (12). In the population studied in the SABE survey, $26.7 \%$ of people living in rural areas are in a situation of monetary poverty. This figure is high, taking into account that the possibilities of economic recovery of the population over 60 are very limited.
On the other hand, data from the United Nations High Commissioner for Refugees (UNHCR) show that in Colombia 3,389,986 people $(7.3 \%$ of the population) have been victims of forced displacement (18). This figure increases significantly in people over 70 years of age who participated in the SABE survey, since $35 \%$ of them stated that they were victims of displacement due to armed conflict or violence. Of these, $5 \%$ of women living in monetary poverty entered into that condition after being 60 years old, and $3.1 \%$ of men.

These figures show the difficulties of the programs to guarantee the minimum level of subsistence to people displaced by violence.

It is also important to analyze the economic protection of the elderly population. A study conducted by Fedesarrollo (Spanish acronym for Foundation for Higher Education and Development) and Fundación Saldarriaga Concha showed that $77.2 \%$ of people over 60 do not receive a pension; only $20 \%$ of women and $27.4 \%$ of men in that group receive a pension (19). In contrast, according to the SABE survey, only $9.8 \%$ of women and $8.6 \%$ of men over 70 report that they receive a pension. In higher income groups, more women over 70 receive a pension, compared to women under 70 years of age. This data could be due to the fact that the division of roles in our society leads to women working at home without pay and to limiting their access to economic activities that allow them to save up for old age; thus, older women can receive substitution pensions, and young women still live with their partner.

Now, the group of younger men benefits significantly more from this provision than those over 70 years. This probably has to do with the fact that in the early and mid-twentieth century, the jobs were informal; furthermore, at first, the pension scheme covered only public sector workers, and it was not until 1967 when the private sector was included in the average premium scheme, through the Colombian Social Security Institute.

In view of the fact that the pension system does not have the necessary coverage, another very important point to provide economic protection 
is the receipt of subsidies for the elderly population. In the population studied, more women under 70 with and without economic poverty receive subsidies compared to women older than 70 years. In contrast, men older than 70 years with and without economic poverty receive more subsidies than those under 70 years of age. Although in the analyzes by subgroups statistically significant differences are observed, when reviewing the specific amount of people receiving subsidies, in no subgroup the total percentage of people receiving this aid is greater than 40\%; these figures coincide with the Mission Aging Colombia: figures, challenges and recommendations study, which reveals a difference of 25 percentage points between the poverty rate of the elderly population (44.7\%) and the total of the population (19.5\%), which reflects the failure of the old-age economic protection system (19).

Finally, when analyzing health conditions, we can see that the health social determinants, which are the circumstances in which people are born, grow, live, work and age, including the health system (20), influence the appearance of certain pathologies, if we consider the Dalgren and Whitehead socioeconomic health model, which explains how social inequalities in health are the result of the interactions of different levels of causative conditions, from the individual to the community level, from individual and non-modifiable risk factors such as age, sex and heredity, personal behaviors and lifestyles (21). We can understand how significant differences in access to public services, the fact of being married and living with the couple, in favor of younger people, in the analysis by generations of both genders, and regardless of the income level, allow chronic diseases in the older groups, in which the prevalence of cardiovascular, respiratory, osteoarticular and diabetes mellitus pathologies were significantly higher.

\section{Conclusions}

The most significant sex differences (to the detriment of women) refer to education (primary education, maximum level attained), to working life (not having worked or having worked without pay due to having to take care of the family, or work mainly in domestic work), to a greater monetary poverty, to economic dependence, to abuse by relatives, to a reduced use of technologies and to the importance of sexuality in their lives.

Regarding disparities by generation, schooling is lower in all those over 70, and in older women, less access to a paid job, greater economic dependence, lower affiliation to the health system under the contributory regime, lower percentage of contribution to the pension system, social participation, access to communication technologies and the importance of sexual life, and more abuse by family members. In men older than 70 years, earlier start of working life; greater dedication to work as a worker, day laborer or being an independent worker; greater monetary poverty; greater economic dependence; lower affiliation to the health system under the contributory regime; lower percentage of contribution to the pension system; less social participation; less access to communication technologies; less knowledge of sexual rights and more abuse by a stranger.

Sex and generation differences are maintained, regardless of the presence or absence of monetary poverty.

From the above it can be inferred that these disparities are related to representations and practices related to gender and age; likewise, changes are seen that are reducing the gap between women and men with respect to educational inequalities. These are less evident in the economic sphere and in the strengthening of women in everyday environments, although there are convincing transformations in the two age groups (or generations) considered in this research, which exhibit greater disadvantages among themselves.

The above pressures to strengthen all policies and programs that allow progress in reducing precarious conditions for all, allowing the universalization of social protection, through non-contributory pensions, for example.

From an intergenerational perspective, differential approaches to aging cannot be 
ignored, associating better living conditions during childhood and adolescence, with a better aging (22). Therefore, the intervention of the State in the care and monitoring of childhood development will be paramount, and should become a driver of development plans.

Along with the essential improvement in the global living conditions of the population as a whole, there must be changes in the representations and social imaginaries underlying the naturalization of sex and generation disparities. Above all, it is necessary to be careful not to introduce other differences, between the winners of active, successful or healthy aging and the losers due to illness and disabilities, affirming various ways of aging and being.

\section{References}

1. Leccardi C, Feixa C. The generation concept in youth theories. Última Década. 2011;19(34):11-32. https://dx.doi.org/ $10.4067 / S 0718-22362011000100002$.

2. Idrovo AJ, Eslava JC, Ruiz-Rodríguez M, Martín Rodríguez J. La otra transición epidemiológica: hitos en el desarrollo de la epidemiología de los factores de riesgo en Colombia. Biomédica. 2008;28:480-96. https://do i.org/10.7705/biomedica.v28i4.54

3. Mejía D, Ramírez MT, Tamayo J. Transición demográfica en Colombia. Reportes del Emisor 116. Bogotá: Banco de la República; 2009.

4. Rami\#rez MT, Te\#llez JP. La educación primaria y secundaria en Colombia en el siglo XX [internet]; 2006. Disponible en: http://repositorio.banrep.gov.co/bit stream/handle/20.500.12134/5397/BO RRADOR\%20379.pdf?sequence $=1 \& \mathrm{i}$ sAllowed $=y$

5. Montoya Ruiz A. Mujeres y ciudadanía plena, miradas a la historia jurídica colombiana. Opinión Jurídica. 2009;8(16):137-48.

6. Bravo R. Condiciones de vida y desigualdad social: una propuesta para la selección de indicadores [internet]. Washington: Cepal; 2000. Disponible en: https://repositorio.cepal.org/handle /11362/31595

7. Fresneda O. Indicadores de inequidad en salud a través de la trayectoria vital [presentación en Power Point]. Bogotá: Observatorio para la Equidad en Calidad de Vida y Salud de Bogotá; 2011.

8. Schneider MC, Castillo-Salgado C, Bacallao J, Loyola E, Mujica OJ, Vidaurre M, Roca A. Métodos de medición de las desigualdades de salud. Rev Panam Salud Publica. 2002;12(6):398-415.

9. Rivillas JC, Gómez-Artistizábal L, Rengifo-Reina HA, Muñoz-Laverde EP. Envejecimiento poblacional y desigualdades sociales en la mortalidad del adulto mayor en Colombia: ipor qué abordarlos ahora y dónde comenzar? Rev Fac Nac Salud Pública. 2017;35(3):369-81. https://doi.org/10. 17533/udea.rfnsp.v35n3a07

10. Ministerio de Salud y Proteccio\#n Social, Departamento Administrativo de Ciencia Tecnología e Innovación (Colciencias), Universidad del Valle, Universidad de Caldas. Encuesta SABE Colombia: situación de salud, bienestar y envejecimiento en Colombia. Bogotá: Pregraf; 2016.

11. Social Watch. El índice de equidad de género [internet]. 2009. Disponible en: http://www.socialwatch.org/sites/d efault/files/IEG2009_esp_0.pdf

12. Departamento Administrativo Nacional de Estadística (DANE). Pobreza monetaria y multidimensional en Colombia: año 2017 [internet]. Boletín Técnico. 2018 mar 22. 
Disponible en: https://www.dane.gov.c o/files/investigaciones/condiciones_vid a/pobreza/bol_pobreza_17.pdf.

13. Cajiao F. La concertación de la educación en Colombia. Revista Iberoamericana de Educación. 2004; (34):31-47.

14. Freixas Farré A. La vida de las mujeres mayores a la luz de la investigación gerontológica feminista. Anuario de Psicología. 2008;39(1):41-57.

15. Farné S, Rodríguez Guerrero DA. Participación de los adultos mayores en las economías de mercado y del hogar en Colombia. Bogotá: Universidad Externado de Colombia; 2014.

16. Gómez Muñoz D, Pineda Duque J. Trabajo y vejez: debates y perspectivas. En: Pineda Duque J et al., compiladores. El trabajo decente en Bogotá: diagnóstico y perspectivas. Bogotá: Ediciones Uniandes-Secretaría Distrital de Desarrollo Económico; 2013.

17. Huenchuan S, Guzmán JM. Seguridad económica y pobreza en la vejez: tensiones, expresiones y desafíos para políticas [internet]. Documento procedente de la Reunión de Expertos sobre Población y Pobreza en América Latina y el Caribe, 14 y 15 de noviembre de 2006, Santiago de Chile. Disponible en: http://www.eclac.org/ celade/noticias/paginas/5/27255/Huen chuan_Guzman.pdf

18. Agencia de la ONU para los Refugiados. Desplazamiento forzado en Colombia [internet]; 2008. Disponible en: https://www.acnur.org/t3/uploads/ media/COI_2821.pdf

19. Fedesarrollo, Fundación Saldarriaga Concha. Misión Colombia envejece: cifras, retos $\mathrm{y}$ recomendaciones. Bogotá; 2015.

20. Organización Mundial de la Salud (OMS). Determinantes sociales de la salud [internet]; 2013. Disponible en: http://www.who.int/social_determi nants/es/

21. Rivillas JC, Molina AN. Métodos para medición de desigualdades y brechas en salud. En: Observatorio para Medición de Desigualdades y Análisis de Equidad en Salud [internet]. Bogotá: Imprenta Nacional, 2015. p. 87-108. Disponible en: https:// www.minsalud.gov.co/sites/rid/Lists/ BibliotecaDigital/RIDE/VS/ED/GCFI/ guia-ross-odes-colombia.pdf

22. Montero-López MP, LópezGiménez MR, Acevedo-Cantero P, Mora-Urda AI. Envejecimiento saludable: perspectiva de género y de ciclo vital. Eur J Inv Health Psychol Educ. 2015;5(1):55-63.

\section{Notes}

a Submitted to the contest for the Guillermo Marroquín Prize to the Best Research Work at the XIII Colombian and Ibero-American Congress of Gerontology and Geriatrics, Barranquilla (Colombia), May 17-19, 2018 